\title{
Tingkat Adopsi Teknologi SRI (System of Rice Intensification) dan Analisis Usahatani Padi di Kecamatan Nagrak Kabupaten Sukabumi
}

\author{
I.Solihah $^{1,}{ }^{1}$. Novita ${ }^{1 a}$ dan S. Masithoh ${ }^{1}$ \\ ${ }^{1}$ Jurusan Agribisnis, Fakultas Pertanian Universitas Djuanda Bogor, \\ Jl Tol Ciawi No. 1 PO Box 35 Ciawi Bogor 16720, \\ ${ }^{a}$ Korespondensi: Ita Novita, Telepon: 0817400272, E-mail: novitazulfa@yahoo.co.id;
}

\begin{abstract}
ABSTRAK
Penelitian ini bertujuan untuk menganalisis karakteristik petani serta mengetahui pendapatan petani padi SRI di Kecamatan Nagrak Kabupaten Sukabumi dan mengetahui bagaimana tingkat adopsi petani terhadap teknologi SRI. Penelitian ini dilakukan di Kecamatan Nagrak Kabupaten Sukabumi Jawa Barat di empat desa yang telah menerapkan SRI yakni Desa Nagrak Utara, Desa Cisarua, Desa Kalaparea dan Desa Nagrak Selatan. Dilaksanakan pada bulan September 2013 dengan jumlah responden sebanyak 40 orang. Analisis data menggunakan analisis deskriptif, analisis usahatani, likert dan regresi berganda. Hasil penelitian ini menunjukkan bahwa petani yang menerapkan teknologi SRI sebagian besar berpendidikan rendah (tidak tamat SD) dengan persentase 56,4\% dengan penghasilan Rp. 3.073.447 dengan luas lahan kurang dari 0,5 ha dan Rp. 7.090.909 dengan luas lahan lebih dari 0,5 ha.
\end{abstract}

\section{PENDAHULUAN}

Kebutuhan lahan untuk pertanian di Indonesia cukup tersedia, tetapi dengan adanya pertumbuhan penduduk dan kebutuhan akan lahan yang terus meningkat, menjadikan potensi akan lahan untuk pertanian menjadi terancam. Konversi lahan sawah terus berlangsung dengan laju konversi sekitar 100 ribu ha/tahun. Konversi lahan sawah tersebut terjadi di sekitar kota besar (provinsi dan kabupaten), kota kecil (kecamatan) dan bahkan sampai di tingkat desa, terutama di pulau Jawa (Deptan, 2011). Selain kegiatan alih fungsi lahan yang semakin tinggi, juga didukung dengan penggunaan bahan-bahan kimia dalam kegiatan produksi bahan pangan yang terus menerus, mengakibatkan kerusakan lahan yang kian hari kian parah.

Pertanian Indonesia sudah sejak lama menggunakan pupuk dan pestisida kimia dalam proses produksi bahan pangan. Hal ini mengakibatkan lahan pertanian mengalami degradasi kesuburan dan kerusakan lahan serta pencemaran lingkungan. Akibatnya produktivitas pun mengalami penurunan dan terjadi inefisiensi usahatani yang berdampak langsung terhadap para petani. Pertambahan penduduk yang terus meningkat setiap tahunnya mengakibatkan tingkat kebutuhan terhadap pangan pun kian meningkat. Di tengah lahan pertanian yang kian hari semakin berkurang diperlukan adanya metode baru untuk meningkatkan hasil produksi pangan, sehingga dapat memenuhi kebutuhan pangan masyarakat saat ini (Direktorat Perluasan dan Pengelolaan lahan, 2013).

Salah satu komoditas yang dijadikan bahan pangan oleh masyarakat Indonesia adalah tanaman padi yang kemudian diolah menjadi beras. Tanaman padi merupakan komoditas strategis dan utama dalam memenuhi kebutuhan pangan nasional. Hal ini disebabkan karena 95 persen rakyat Indonesia masih mengkonsumsi beras sebagai sumber bahan pangan dan karbohidrat (Ditjen Bina Produksi Tanaman Pangan, 2004).

Berdasarkan data BPS (2012) daerah di Indonesia yang menjadi penghasil padi terbanyak terdapat di pulau Jawa. Jawa 
Timur berada di posisi pertama sebagai daerah penghasil beras tertinggi, diikuti oleh Jawa Barat di posisi kedua dan Jawa Tengah di posisi ketiga. Renstra Kementrian Pertanian (2010) menargetkan sasaran produksi padi tahun 2012 untuk daerah Jawa Timur sebanyak 10.911.780 ton, Jawa Barat sebanyak 12.002.586 ton dan Jawa Tengah sebanyak 9.689.652 ton. BPS (2012) juga memperlihatkan bahwa tidak semua daerah dapat memenuhi target sasaran produksi tersebut, ini terlihat dari hasil produksi padi tahun 2012 untuk daerah Jawa Timur mencapai 12.198.707 ton, Jawa Barat mencapai 11.271.861 ton dan Jawa Tengah mencapai 10.232.934 ton, dari angka ini dapat dilihat bahwa daerah yang belum mencapai target sasaran produksi adalah Jawa Barat.

Pada tahun 2011 luas panen padi mengalami sedikit penurunan dibanding tahun 2010, hal ini diikuti pula dengan penurunan hasil produksinya. Luas panen turun sekitar 3,5 persen sedangkan produksi padi turun hanya 0,08 persen hal inilah yang menjadi sebab atas ketidaktercapaian target sasaran produksi padi pada tahun 2012 (Jabar Dalam Angka, 2012).

Dalam menghadapi dampak perubahan iklim dan sulitnya untuk melakukan perluasan areal lahan baru, maka peningkatan produktivitas menjadi upaya yang paling tepat. Saat ini salah satu teknologi yang tengah berkembang di masyarakat untuk meningkatkan produksi beras nasional dalam kegiatan budidaya padi adalah metode SRI (System of Rice Intensification). Teknologi budidaya padi SRI salah satunya adalah dalam rangka menerapkan budidaya padi hemat air, hemat benih $(5-8 \mathrm{~kg} / \mathrm{ha})$ karena tanam 1 batang dengan umur bibit muda (kurang dari 15 hari) (Deptan, 2011).

Metode baru yang mulai dikenal di Indonesia sekitar tahun 1999 ini dipandang dapat menyelesaikan beberapa permasalahan terkait kebutuhan pangan nasional saat ini, karena metode ini merupakan metode yang ramah lingkungan dan mampu meningkatakan produktivitas (Anugrah, et.all, 2008). Namun demikian, munculnya metode baru di dunia pertanian tidak mudah untuk langsung diadopsi oleh petani. Banyak faktor-faktor yang mempengaruhi petani dalam memutuskan mengadopsi metode baru. Meskipun sudah banyak penelitian dilakukan mengenai manfaat dan keuntungan penerapan metode SRI, tetap saja masih banyak petani yang belum mengadopsi metode ini. Oleh karena itu peneliti melakukan penelitian mengenai Tingkat Adopsi Teknologi SRI dan Analisis Usahatani Padi di Kecamatan Nagrak Kabupaten Sukabumi.

Kecamatan Nagrak di Kabupaten Sukabumi memiliki 10 desa meliputi Desa Babakan Panjang, Desa Balekambang, Desa Cihanjawar, Desa Cisarua, Desa Darmareja, Desa Girijaya, Desa Kalaparea, Desa Nagrak Selatan, Desa Nagrak Utara, Desa Pawenang. Luas lahan Kecamatan Nagrak 6.743.342 ha yang dibagi ke dalam beberapa sektor pertanian meliputi lahan untuk sawah seluas $1.623,4$ ha, tegalan $2.085,5$ ha, pemukiman 467,91 ha, perkebunan 754,39 ha, kehutanan 1.710 ha (BP3K Nagrak, 2011).

Berdasarkan data yang diperoleh, dari 10 desa di Kecamatan Nagrak yang membudidayakan padi, empat desa diantaranya sudah menerapkan teknologi SRI dan sisanya ada yang pernah merapkan SRI dan belum pernah sama sekali atau masih menggunakan metode konvensional dan teknologi lain seperti PTT. Jumlah poktan dari 10 Desa yang ada di Kecamatan Nagrak totalnya berjumlah 73 Poktan yang hampir 90\% dari Poktan tersebut membudidayakan padi. Terdapat empat Poktan dari 73 Poktan yang baru menerapkan SRI, yaitu Poktan Sukasari dari Desa Nagrak Utara, Poktan Wanamukti dari Desa Cisarua, Poktan Saritani dari Desa Kalaparea dan Poktan Bumi Asih I dari Desa Nagrak Selatan (BP4K Nagrak, 2012).

Data diatas menunjukkan bahwa tingkat adopsi petani yang berada di 
Kecamatan Nagrak terhadap teknologi SRI masih sangat rendah. Hal inilah yang menjadi beberapa tinjauan perumusan masalah yang melatarbelakangi penelitian ini diantaranya (1) bagaimana karakteristik petani yang menerapkan teknologi SRI dalam budidaya padi, (2) bagaimana tingkat pendapatan usahatani padi yang menerapkan (3) bagaimana tingkat adopsi teknologi SRI pada budidaya padi di Kecamatan Nagrak kabupaten Sukabumi.

Penelitian ini bertujuan untuk menganalisis karakteristik petani yang ada di Kecamatan Nagrak Kabupaten Sukabumi. pendapatan usahatani padi yang menggunakan teknologi SRI dan menganalisis tingkat adopsi teknologi SRI pada budidaya padi di Kecamatan Nagrak Kabupaten Suakbumi.

\section{BAHAN DAN METODE}

\section{Teori Adopsi Inovasi}

Ban dan Hawkins (2003) mendefinisikan inovasi adalah suatu gagasan, metode atau objek yang dianggap sebagai sesuatu yang baru, tetapi tidak selalu merupakan hasil dan penelitian mutakhir. Sedangkan adopsi merupakan kegiatan menerapkan inovasi pada skala besar setelah membandingkannya dengan metode lama. Dalam kegiatan adopsi ada yang dinamakan dengan proses difusi inovasi, dimana proses tersebut dimulai dari kesadaran adalah ketika pertama kali mendengar tentang inovasi, minat adalah ketika petani mencari informasi lebih lanjut, evaluasi, merupakan kegiatan menimbang manfaat dan kekurangan inovasi, mencoba adalah ketika petani menguji sendiri inovasi pada skala kecil, adopsi merupakan kegiatan menerapkan inovasi pada skala besar setelah membandingkannya dengan metode lama.

\section{Gambaran Umum Teknologi SRI}

\section{System of Rice Intensification}

(SRI) adalah teknik budidaya tanaman padi yang mampu meningkatkan produktivitas padi dengan cara mengubah pengelolaan tanaman, tanah, air dan unsur hara, terbukti telah berhasil meningkatkan produktivitas padi sebesar $50 \%$ bahkan dibeberapa tempat mencapai lebih dari 100\% (Mutakin, 2008).

\section{Analaisis Usahatani}

Perlunya analisis usahatani agar dapat diketahui suatu usahatani berjalan efektif dan efisien. Dikatakan efektif bila petani atau produsen dapat mengalokasikan sumberdaya dengan sebaik-baiknya dan dikatakan efisien bila sumberdaya yang digunakan menghasilkan output yang melebihi input. Pada analisis usahatani maka data tentang penerimaan, biaya dan pendapatan usahatani perlu diketahui (Soekartawi, 2006).

\section{Kerangka Pemikiran}

Padi merupakan salah data komoditas yang dijadikan bahan pangan pokok di Indonesia. Krisis pangan nasional menjadi sebuah permasalahan mendasar saat ini seiring bertambahnya populasi penduduk, konversi lahan pertanian ke non pertanian dan degradasi kesuburan lahan akibat budidaya yang tidak ramah lingkungan. Akibatnya produksi padi kian hari semakin menurun sedangkan kebutuhan terus beranjak naik. Target pencapaian produksi padi nasional surplus 10 juta ton tahun 2014 tidak diimbangi dengan keanaikan produksi padi di Jawa Barat sebagai salah satu sentra produksi. Ini terlihat dari tingkat poduksi yang terus menurun dari tahun 2009 (BPS 2009).

Upaya yang sudah dijalankan pemerintah kearah itu adalah dengan menerapkan program intensifikasi, ekstensifikasi, diversifikasi dan rehabilitasi. Salah satu metode intensifikasi dalam meningkatkan produksi padi nasional adalah dengan menerapkan teknologi baru yang dikenal dengan metode SRI (System of Rice Intensification). Telah Banyak penelitian mengenai keuntungan menerapkan teknologi baru ini diantaranya penelitian Ningtyas (2011) mengenai analisis yang membandingkan penerapan teknologi SRI 
dengan konvensional, dalam penelitian ini disimpulkan bahwa penerapan metode SRI lebih menguntungkan bagi petani dibanding metode konvensional.

\section{Lokasi Dan Waktu Penelitian}

Penelitian ini dilaksanakan di Kecamatan Nagrak Kabupaten Sukabumi Jawa Barat di empat desa yang telah menerapkan SRI yakni Desa Nagrak Utara, Desa Cisarua, Desa Kalaparea dan Desa Nagrak Selatan. dilaksanakan pada bulan September 2013

\section{Jenis Dan Sumber Data}

Data yang digunakan dalam penelitian ini terdiri atas data primer dan data sekunder. Data primer diperoleh melalui wawancara langsung dengan petani menggunakan kuesioner yang telah disiapkan sebelumnya. Data sekunder diperoleh dari sumber-sember data seperti buku yang berkaitan dengan penelitian, BP3K Kecamatan Nagrak, BPS, jurnal dan sumber data yang relevan.

\section{Metode Pengambilan Sampel}

Analisis kualitatif dan kuantitaf dilakukan berdasarkan data primer dan sekunder dari hasil penelitian yang telah dilakukan. Analisis kualitatif telah diuraikan secara deskriptif, sedangkan analisis kuantitatif diolah dengan menggunakan Microsoft Excel.

\section{Analisis Deskriptif}

Analisis ini bertujuan untuk menggambarkan lokasi penelitian, karakteristik petani, tingkat adopsi SRI di Kec. Nagrak dan pendapatan usahatani. Karakteristik petani meliputi umur, jenis kelamin, pendidikan, status kepemilikan lahan, luas lahan, pengalaman usahatani. Analsis deskriptif merupakan upaya untuk menginterpretasikan data yang nanti diperoleh yang kemudian diolah.

\section{Analisis usahatani}

Soekartawi (2006), menjelaskanb ahwa untuk menganalisis usahatani memerlukan data mengenai penerimaan, biaya, pendapatan usahatani. Penerimaan merupakan perkalian antara jumlah produksi dengan harga jual, biaya usahatani merupakan semua biaya yang dikeluarkan dalam usahatani dan pendapatan merupakan selisih antara penerimaan dan pengeluaran.

Menurut Soekartawi (2006) rumus penerimaan, biaya dan pendapatan adalah sebagai berikut :

$\mathrm{TR}=\mathrm{Y} \times \mathrm{Py}$

Keterangan :

$\mathrm{TR} \quad=$ Penerimaan Total

$\mathrm{Y}=$ Produksi yang diperoleh

Py $=$ Harga $\mathrm{Y}$

$\mathrm{TC}=\mathrm{FC}+\mathrm{VC}$

Keterangan :

TC = Biaya Total

$\mathrm{FC} \quad=$ Fix Cost (Biaya Tetap)

$\mathrm{VC}=$ Variable Cost (Biaya Variabel)

$\mathrm{Pd}=\mathrm{TR}-\mathrm{TC}$

Keterangan :

$\mathrm{Pd} \quad=$ Pendapatan Usahatani

TR = Penerimaan Total

$\mathrm{TC}=$ Biaya Total

R/C Ratio (Revenue Cost Ratio) merupakan efisiensi usaha, yaitu ukuran perbandingan antara Penerimaan usaha $($ Revenue $=\mathrm{R})$ dengan Total Biaya $($ Cost $=T C)$. Nilai R/C digunakan untuk mengetahui apakah suatu usaha menguntungkan atau tidak.

\section{Skala Likert}

Skala likert digunakan untuk mengukur sikap, pendapat dan persepsi seseorang atau sekelompok orang tentang fenomena sosial. Skala likert yang akan diukur dijabarkan menjadi indikator variabel. Indikator tersebut dijadikan sebagai titik tolak untuk menyusun itemitem yang dapat berupa pernyataan atau pertanyaan (Sugiyono, 2010).

\section{HASIL DAN PEMBAHASAN}

\section{Keadaan Umum Wilayah Penelitian}

Kecamatan Nagrak merupakan salah satu wilayah bagian dari Kabupaten 
Sukabumi terletak $69 \mathrm{~km}$ dari ibukota Kabupaten Sukabumi, $128 \mathrm{~km}$ dari ibukota provinsi Jawa Barat dan $82 \mathrm{~km}$ dari ibukota negara. Wilayah ini sebelah Utara berbatasan dengan Kecamatan Ciambar, sebelah Barat berbatasan dengan Kecamatan Parungkuda, sebelah Timur berbatasan dengan Kecamatan Caringin, sebelah Selatan berbatasan dengan Kecamatan Cibadak. Kecamatan Nagrak memiliki sepuluh desa yang terdiri atas Desa Kalaparea, Desa Giri Jaya, Desa Darmareja, Desa Pawenang, Babakan Panjang, Desa Cihanyawar, Desa Nagrak Utara, Desa Nagrak Selatan, Desa Cisarua dan Desa Balekambang.

Para petani di Kecamatan Nagrak pada umumnya memiliki lahan yang sempit. Sebanyak 4,4 persen petani memiliki lahan yang luasnya rata-rata 0,01-0,25 Ha, sedangkan petani yang memiliki luas lahan rata-rata 0,51-1 $\mathrm{Ha}$ sebanyak 13,2 persen dan 4,4 persen petani memiliki luas lahan lebih dari $1 \mathrm{Ha}$, sisanya petani yang rata-rata memiliki luas lahan kurang dari $100 \mathrm{~m}^{2}$ (Kecamatan Dalam Angka, 2012).

\section{Keadaan Pendududk Berdasarkan Tingkat Pendidikan}

Tingkat pendidikan penduduk di Kecamatan Nagrak masih sangat rendah. Ini dibuktikan dengan nilai persensentase tertinggi yakni 44,3 persen penduduk Nagrak hanya tamat SD, diikuti oleh penduduk dengan tingkat pendidikan SMP sebesar 12,8 persen, tidak tamat SD 9,3 persen, tamat SMA 8,7 persen, penduduk yang tidak sekolah 3,2 persen dan penduduk lulusan sarjana hanya 1,6 persen

Tabel 1. Tingkat Pendidikan Penduduk Kecamatan Nagrak Tahun 2014

\begin{tabular}{cccc}
\hline No & Tingkat Pendidikan & Jumlah Jiwa & Persentase (\%) \\
\hline 1 & Tidak Sekolah & 7653 & 3.2 \\
2 & Tidak Tamat SD & 7548 & 9.3 \\
3 & SD & 35880 & 44.3 \\
4 & SMP & 10412 & 12.8 \\
5 & SMA & 7066 & 8.7 \\
6 & Sarjana & 1332 & 1.6 \\
\hline
\end{tabular}

Sumber : Kantor Kec. Nagrak (diolah), 2014

\section{Keadaan Penduduk Berdasarkan Mata Pencaharian}

Mata pencaharian penduduk kecamatan Nagrak cukup beragam dari mulai penduduk yang berprofesi sebagai PNS, POLRI, Petani, wiraswasta, pegawai swasta dan lain-lain. Berikut ini disajikan data penduduk Kecamatan Nagrak berdasarkan mata pencaharian. Tabel 2 menunjukan sebaran mata pencaharian penduduk di kecamatan Nagrak tahun 2014

Tabel 2. Sebaran mata pencaharian penduduk di kecamatan Nagrak tahun 2014

\begin{tabular}{clcc}
\hline No & \multicolumn{1}{c}{ Pekerjaan } & Jumlah Jiwa & Persentase (\%) \\
\hline 1 & PNS/POLRI & 640 & 1.8 \\
2 & Pegawai Swasta & 1.767 & 5 \\
3 & Petani & 3.631 & 10.3 \\
4 & Wiraswasta & 4.417 & 12.5 \\
5 & Lainnya & 24.789 & 70.3 \\
\hline
\end{tabular}

Sumber : Kantor Kec. Nagrak (diolah), 2014. 


\section{Jumlah dan Kepadatan Penduduk}

Jumlah penduduk di Kecamatan Nagrak hingga Februari tahun 2014 terdapat sebanyak 80.871 jiwa. Jumlah penduduk laki-laki sebanyak 41.747 jiwa dan penduduk perempuan sebanyak 39.124 jiwa. Jika kita bandingkan dengan luas lahan di Kecamatan Nagrak, tingkat kepadatan penduduk di Kecamatan Nagrak masih cukup rendah karena masih sangat besar luas lahan yang digunakan untuk kegiatan pertanian. Jumlah rumah tangga di Kecamtan Nagrak mencapai 23.165 KK dengan rata-rata 3-4 jiwa per rumah tangga.

\section{Gambaran Umum Responden}

Responden merupakan petani yang tergabung dalam keanggotaan kelompok tani yang mendapatkan bantuan hibah pengembangan teknologi SRI pada tahun 2013 selama satu kali masa tanam. Responden merupakan petani yang membudidayakan padi yang baru menerapkan teknologi SRI dan tergabung dalam anggota kelompok tani di Kecamatan Nagrak Kabupaten Sukabumi.

Kelompok tani yang dijadikan responden merupakan anggota kelompok tani yang mendapatkan hibah dari pemerintah untuk penerapan teknologi SRI. Pada tahun 2013 terdapat 4 Poktan di Kecamatan Nagrak yang menerima bantuan hibah, besarnya bantuan tersebut adalah Rp. 40 juta/Poktan. Diantara kelompok Tani yang mendapat bantuan adalah kelompok tani Bumi Asih dari Desa Nagrak Selatan, kelompok tani Sari Tani dari Desa Kalaparea, kelompok tani Wanamukti dari Desa Cisarua dan kelompok tani Sukasari dari Desa Nagrak Utara.

Jumlah responden yang dijadikan sampel adalah sebanyak 40 orang. Jumlah tersebut diambil setelah dilakukan pengocokan dari jumlah populasi responden dari empat Poktan sebanyak 148 orang. Maka terpilihlah 18 responden dari Poktan Bumi Asih, 3 responden dari poktan Wanamukti, 11 responden dari Poktan Saritani dan 8 responden dari Poktan Sukasari

\section{Karakteristik Responden}

Karakteristik atau responden yang diamati meliputi umur, pendidikan, status kepemilikan lahan, luas lahan serta pengalaman usahatani. Berdasarkan hasil penelitian rentang umur responden dibagi ke dalam 6 rentang yakni rentang 30-40 tahun sebanyak 5 responden, 41-50 tahun sebanyak 7 orang, 51-60 tahun sebanyak 10 orang, $61-70$ sebanyak 12 orang, $71-80$ sebanyak 4 orang dan $81-90$ sebanyak 1 orang.

Kebanyakan responden merupakan responden yang hanya lulusan SD dengan persentase tertinggi yakni 56,4\%. Responden yang tidak tamat SD berada di posisi kedua dengan persentase $30,7 \%$, selanjutnya lulusan SMP berada di posisi ketiga dengan persentase $7,6 \%$ dan sisanya responden dengan pendidikan SMA dan S1 dengan persentase hanya sebesar $2,5 \%$.

Responden dengan kepemilikan lahan kurang dari setengah hektar berada pada posisi pertama berjumlah 29 responden dengan persentase 74,3\%. Sedangkan di posisi kedua diduduki oleh reponden dengan luas lahan lebih dari setengah hektar sampai satu hektar berjumlah 7 orang dengan persentase 17,9 $\%$ dan sisanya adalah responden yang memiliki luas lahan lebih dari satu hektar dengan persentase sebesar 2,5\%.

Rentang pengalaman petani dengan persentase tertinggi terdapat pada rentang nomor satu yakni $0-20$ tahun sebesar 43,5\% sedangkan sisanya adalah rentang 21 - 40 tahun dan 41 - 60 tahun dengan besar persentase yang sama yaitu 28,2 \% . Sedangkan untuk status kepemilikan lahan, penulis bagi ke dalam kategori sewa dan pemilik. Sewa berarti responden yang melakukan usahatani tidak dilakukan pada 
lahan sendiri tetapi pada lahan orang lain, dan pemilik berarti sebaliknya. Hasil data menunjukkan bahwa responden sebanyak $30 \%$ merupakan responden dengan status kepemilikan lahan sewa dan sisanya sebanyak $70 \%$ merupakan pemilik.

\section{Analisis Usahatani Padi Teknologi SRI}

Pendapatan yang diperoleh oleh petani berdasarkan biaya tunai pada lahan garapan sempit adalah sebesar $\mathrm{Rp}$. 784.312 sedangkan pada lahan garapan luas sebesar Rp. 1.056.668. Pendapatan berdasarkan biaya yang diperhitungkan pada lahan garapan sempit yaitu sebesar Rp. 500.034 dan pada lahan garapan luas sebesar Rp. 1.897.287. Data di atas menunjukkan bahwa pendapatan yang diperoleh oleh petani dengan lahan garapan sempit lebih kecil dibandingkan dengan petani yang memiliki lahan garapan luas. Ini menunjukkan bahwa luas lahan cukup berpengaruh terhadap keuntungan usahatani yang diperoleh.

Tabel 3. Analisis Pendapatan Usahatani Padi Teknologi SRI (1 musim tanam)

\begin{tabular}{lcc}
\hline \multirow{2}{*}{ Uraian } & \multicolumn{2}{c}{ Usahatani Dengan Lahan Garapan } \\
\cline { 2 - 3 } & Sempit $<0.5$ ha (Rp/Ha) & Luas $>0.5$ ha (Rp/Ha) \\
\hline Penerimaan (Rp/Ha) & $2,191,034$ & $4,800,000$ \\
Penerimaan Tunai & 882,431 & $2,290,909$ \\
Penerimaan Diperhitungkan & $3,073,465$ & $7,090,909$ \\
Total Penerimaan (Rp/Ha) & & \\
Pengeluaran & $1,406,722$ & $3,743,332$ \\
Pengeluaran Tunai & 388,397 & 393,622 \\
Pengeluaran yang Diperhitungkan & $1,789,119$ & $4,136,954$ \\
Total Pengeluaran (Rp/Ha) & 784,312 & $1,056,668$ \\
Pendapatan atas Biaya Tunai (Rp/Ha) & & $1,897,287$ \\
Pendapatan atas Biaya yang & 500,034 & \\
Diperhitungkan (Rp/Ha) & & \\
\hline Sumber: Data Prim & &
\end{tabular}

Sumber : Data Primer (diolah).

\section{Penerimaan Usahatani Padi dengan Menerapkan Teknologi SRI}

Produksi rata-rata padi dengan menerapkan SRI dalam satu kali masa tanam dalam total luas lahan 0,69 ha adalah 3,09 ton/ha. Hasil ini sudah sesuai dengan target yang diinginkan oleh pemerintah terhadap tujuan penerapan teknologi SRI untuk kenaikan produktifitas mencapai $6-8$ ton/ha.

Penerimaan yang diperoleh petani dengan luas lahan sempit lebih kecil dibandingkan dengan penerimaan yang diperoleh oleh petani dengan lahan yang luas. Penerimaan yang diperoleh oleh petani dengan lahan sempit kurang dari 0.5 ha hanya Rp 3.073.447 sedang penerimaan yang diperoleh oleh petani dengan luas lahan lebih dari 0.5 ha mencapai $\mathrm{Rp}$. 7.090. 909. Hal ini memperlihatkan bahwa luas lahan berpengaruh terhadap jumlah penerimaan yang diperoleh petani.

Total biaya yang dikeluarkan oleh petani dengan lahan garapan sempit jauh lebih rendah dibandingkan dengan total biaya yang dikeluarkan oleh petani dengan lahan garapan luas. Total biaya dengan lahan garapan kurang dari 0.5 hektar sebesar Rp. 1.789.119, sedangkan biaya total yang dikeluarkan oleh petani dengan lahan garapan lebih dari 0.5 hektar sebesar Rp. 4.136.954. Tabel 4 menunjukan perbandingan penerimaan usahatani padi teknologi SRI. 
Tabel 4. Perbandingan Penerimaan Usahatani Padi Teknologi SRI.

\begin{tabular}{lcc}
\hline \multicolumn{1}{c}{ Penerimaan per musim tanam } & \multicolumn{2}{c}{ Luas lahan } \\
& Sempit $<0.5$ ha & Luas $>0.5$ ha \\
\hline Penerimaan tunai (GKP yang dijual Rp/Ha) & $2,191,034$ & $4,800,000$ \\
Penerimaan tidak tunai (padi yang dikonsumsi Rp/Ha) & 882,413 & $2,290,909$ \\
Total penerimaan (Rp) & $3,073,447$ & $7,090,909$ \\
\hline
\end{tabular}

Sumber : Data Primer (diolah)

Tingkat Adopsi Teknologi SRI di Kecamatan Nagrak Sukabumi

Peneliti ingin mengetahui bagaimana tingkat proses adopsi teknologi SRI di Kecamatan Nagrak Kabupaten Sukabumi. Skala Likert digunakan untuk mendapatkan gambaran mengenai derajat persepsi responden pada setiap tingkatan peroses adopsi.

Jumlah responden dari penelitian ini yaitu 40 orang dengan total pertanyaan yang diajukan melalui kuisioner sebanyak 18 pertanyaan dengan bobot setiap pertanyaan dimulai dari 1 hingga 4. Dengan demikian akan menghasilkan angka indeks dari yang terendah yaitu 18 hingga yang tertinggi yaitu 72 . Rentang yang didapat yaitu 18-28 untuk (kesadaran), 29- 39 (minat), 4050(evaluasi), 51-61 (mencoba) dan 6272(adopsi).

Setelah data dikumpulkan dan dihitung diperoleh rata-rata dari seluruh jawaban responden sebesar 49,65. Angka ini menunjukkan bahwa tingkatan adopsi teknologi SRI di Kecamatan Nagrak baru mencapai tingkatan evaluasi.

\section{KESIMPULAN DAN IMPLIKASI KEBIJAKAN}

\section{Kesimpulan}

Produksi padi dengan menggunakan teknologi SRI sudah mencapai target peningkatan produsi padi sebanyak 6 ton/ha. Teknologi SRI pun menghasilkan keuntungan untuk para petani dimana bisa dilihat dari nilai $\mathrm{R} / \mathrm{C}=2$. Sedangkan tingkat adopsi para petani di kecamatan
Nagrak baru ada pada tingkat mengevaluasi teknologi SRI tersebut.

\section{Implikasi Kebijakan}

Kegiatan usahatani dengan menerapkan teknologi SRI perlu terus dilanjutkan, karena selain dapat meningkatkan hasil produksi dan pendapatan usahatani.

\section{DAFTAR PUSTAKA}

Agung, IGN. 2005. Manajemen Penulisan Skripsi, Tesis dan Disertasi : Kiatkiat Untuk Mempersingkat Waktu penulisan Karya Ilmiah yang Bermutu. Jakarta. PT. Raja Grafindo persada.

Anugrah, et.all. 2008. Gagasan dan Implementasi System of Rice Intensification dalam Kegiatan Budidaya Padi Ekologis (BPE). Jurnal Analisis Kebijakan Pertanian vol 6 No.1, Maret 2008 : 75-99.

Astuti, R.B. 2007. Penerapan Teknologi System Of Rice Intensification (SRI) di Desa Margahayu Kabupaten Tasikmalaya. [Skripsi]. Program Studi Manajemen Agribisnis. IPB. Bogor.

Bakar, Abu. 2010. Agribisnis; Teori dan Aplikasi. GP Press. Jakarta.

Ban, Van den \& Hawkins. 2003. Penyuluhan Pertanian. Kanisius. Yogyakarta.

Basuki, Thohir. 2007. Analisis Pendapatan Usahatani Padi dan Faktor-faktor yang Mempengaruhi Petani untuk 
Menanam Padi Hibrida ; Studi

Kasus di Kecamatan Cibuaya

Kabupaten Karawang Jawaw Barat.

[Skripsi]. Program Studi

Manajemen Agribisnis Faperta.

IPB. Bogor.

BPS. 2012. Luas panen, Produksi Padi

Berdasarkan

Provinsi.

www.bps.go.id. (Diakses, 06

Agustus 2013).

BPS. 2009. Luas Panen, Produksi dan

Produktifitas Padi di Jawa Barat.

www.bps.go.id. (Diakses, 06

Agustus 2013)

BP3K. 2011. Keragaan Pertanian

Kecamatan Nagrak. BP3K Nagrak.

Sukabumi.

BP3K. 2013. Monografi

Kecamatan Nagrak. BP3K. Nagrak.

BP4K. 2012. Data Dasar Kelompok Tani

(GAPOKTAN). BP4K Kabupaten

Sukabumi. Sukabumi. 